\section{JDF expands research effort}

Buoyed by recent advances in diabetes research, such as the cadaveric islet cell transplantation technique reported on page 750, the Juvenile Diabetes Foundation International (JDF) announced last month that it is to double diabetes research funding to $\$ 120$ million for FY01.

The New York-based group convened an expert panel to review diabetes research and define new priority areas for JDF-funded programs. These include the identification of genesthat predispose peopleto diabetesand its complications; studies aimed at extending the period between early disease diagnosis and its full manifestation; islet transplantation tolerance; stem cell therapy and $\beta$-cell expansion. Details of how to apply for JDF Special Research Grants can be found at http://www.jdf.org.

And in a continued effort to makeitswork international, the JDF announced a new, five-year, $\$ 7$ million joint research initiative with the television charity Telethon Italia, to begin in April 2001. The initiative will fund multidisciplinary and multicenter Italian projects in genetics, immunology, islet transplantation and gene therapy. A joint Telethon/JDF scientific committee will review research proposals this October.

Francesca Pasinelli, Telethon's director of scientific development, says "this is the first time that a US foundation is to support multicenter interdisciplinary work in Italy."

In May, the group opened the JDF Center for the Prevention of Type 1 Diabetes at Turku University Hospital, Finland. The Center will receive $\$ 550,000$ a year for fiveyears to evaluate $20 \%$ of all newborn Finnish babies for their inherited risk of developing diabetes. Thegroup also announced a $\$ 6$ million collaboration with the Australian National Health and Medical Research Council to develop the first Type 1 diabetes vaccine. Similar partnershipsexist with institutions and charities in Great Britain and Sweden.

Martina Ballmaier, Milan

\section{Beanie Baby ${ }^{\circledast}$ profits support AIDS Foundation}

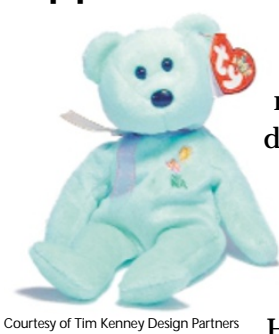

As well as adding to your kids' growing mass of stuffed, cuddly toys, buying the latest Beanie Baby ${ }^{\circledR}$ available in stores this monthcould also benefit HIV positive women and children around the world, since profits from its sale will be donated to the Elizabeth Glaser Pediatric AIDS Foundation. Thenew toy was created in memory of Elizabeth and Paul Glaser'sdaughter, Ariel, who died from the disease in 1988.

The Foundation uses its funds to prevent the transmission of HIV/AIDS from mother to child and is currently trying to raise $\$ 12$ million to buy the vertical transmission-blocking drug, nevirapine, to treat the estimated 2.4 million infected pregnant women worldwide (Nature Med. 5, 1093; 1999).

K.B.

\section{WHO under attack on HIV drug policy}

The World Health Organization (WHO) is under increasing pressure from its member states to become more proactive in the dispute over sales of HIV/AIDS drugs to developing countries. It al so faces criticism on itspolicies regarding distribution of such drugs in the Third World.

DuringitsAnnual Assembly in Genevain mid-May, theWHO wascalled upon by rep-

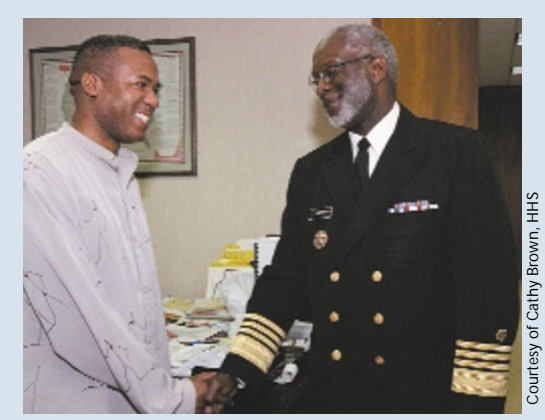

South Africa signs MoU with US

The South African Medical Research Council (MRC) has signed a Memorandum of Understanding (MoU) with the US for " $\mathrm{co}$ operation in the fields of Public Health and Biomedical Research," making it the first African research institute to do so. MRC President William Makgoba met US Surgeon General David Satcher in Washington, DC, to sign the agreement last month. resentatives from Brazil, Uganda, M exico and South Africa to create a computerized database of information on international prices of HIV/AIDS drugs for use by member state governments. However, WHO advisor Michael Schultz was quick to respond that creating and maintaining such a database was beyond the resources of the group, as worldwide prices change daily.

The WHO's reluctance to take on such a task was repeated last month by senior WHO executive, Daniel Tarantola, during a French radio show in which he also admitted that, despite the recent announcement by UNAIDS in conjunction with five major pharmaceutical companies to distribute AIDS drugs at drastically reduced prices to developing countries (see www.nature.com/nm/biomedical_news/west.htm), "negotiations concerning pricing had not begun."

In addition, a WHO document on antiretroviral drug use in the Third World released in $\mathrm{M}$ arch is coming under increasing scrutiny for its lack of medical credibility. The document states that although scientific evidence that a single dose of the drugnevirapine(NVP) prevents mother-tochild transmission (MTCT) of HIV, there is "currently insufficient information to recommend wide-scale implementation of
NVP for MTCT prevention." Thearticlecites a study in which three of fourteen women given a single dose of NVP devel oped resistant HIV strains. Criticism stems from the fact that this case seems to be the only report of NVP resistance so far, despite the drug's having been tested in hundreds of women in clinical trials.

TheWHO's position, which goes against advice of an expert panel convened to report on NVP's effect on vertical transmission, is inexplicable and infuriating to observers. Arthur Ammann, head of the California-based Global Strategies for HIV Prevention, a not-for-profit group that funds HIV research, notesthat theWHO supports the use of the broad-spectrum antibiotic Bactrim to treat secondary infections in HIV-infected patients: "I think WHO is inconsistent in itsargument." Bactrim given to treat such secondary HIV infections as malaria, Salmonella and bacterial pneumonia may result in pathogen resistance in about half of the patients treated, he says.

The WHO's lack of support for NVP has had real implications. In June, South African Health Minister Manto Tshabala-Msimang used this as an excusefor refusing the drug to pregnant women treated in thecountry's public health system.

Myrna E. Watanabe, Connecticut 